\title{
Nitrobenzene-induced hormonal disruption, alteration of steroidogenic pathway, and oxidative damage in rat: protective effects of Vernonia amygdalina
}

Johnson O. Oladele ${ }^{1 *}$, Oyedotun M. Oyeleke ${ }^{1}$, Oluwaseun T. Oladele ${ }^{2}$, Oluwafeyisayo D. Babatope ${ }^{1}$ and Olaide O. Awosanya ${ }^{1}$

\begin{abstract}
Background: Infertility is a global health burden which affect more than $15 \%$ of couples' population. An impaired hormonal balance, oxidative stress and alteration in the physiological function of the reproductive organ are factors leading to infertility. The present study investigated the protective role of methanolic leaf extract of Vernonia amygdalina (MLVA) against Nitrobenzene-induced oxidative testicular damage and hormonal imbalance in rats. Thirty sexually active male wistar rats were sorted into five groups, each group containing six rats. Group I received distilled water while 100 $\mathrm{mg} / \mathrm{kg}$ bw of Nitrobenzene was administered to groups (II, III, IV and V) to induce testicular damage and hormonal imbalance. Group III and IV were treated with oral administration of $200 \mathrm{mg} / \mathrm{kg}$ bw and $400 \mathrm{mg} / \mathrm{kg}$ bw of MLVA respectively and group $\mathrm{V}$ with vitamin $\mathrm{E}$ for 14 days.

Results: Nitrobenzene-treated rats showed significant $(P<0.05)$ decrease in the body weight gain, testis and epididymis weights. However, upon administration of MLVA or vitamin E, these changes were significantly reversed in Nitrobenzenetreated rats. Also, Nitrobenzene significantly $\left(P^{<} 0.05\right)$ induced endocrine disruption as shown by decreased activities level of serum Thyroid stimulating hormone (TSH), luteinizing hormone (LH), follicle stimulating hormone (FSH), prolactin, testosterone, triiodothyronine (T3), and tetraiodothyronine (T4). Administration of Nitrobenzene also induced oxidative damage as shown by increased level of testicular lipid peroxidation (MDA), and decreased levels of glutathione (GSH). Histological studies of the testes revealed mild congestion of interstitial vessels and oedema in rats administered Nitrobenzene only.
\end{abstract}

Conclusion: Taken together, MLVA obliterated the adverse effects of Nitrobenzene on the antioxidant enzymes, markers of testicular oxidative damage, endocrine and testicular structure in rats.

Keywords: Infertility, Hormonal imbalance, Steroidogenesis, Endocrine, Nitrobenzene, Vernonia amygdalina

\footnotetext{
*Correspondence: oladelejohn2007@gmail.com;

jo.oladele@kingsuniversity.edu.ng

'Department of Chemical Sciences, Faculty of Science, Kings University,

Ode-Omu, Osun State, Nigeria

Full list of author information is available at the end of the article
}

\section{Springer Open}

(c) The Author(s). 2020 Open Access This article is licensed under a Creative Commons Attribution 4.0 International License, which permits use, sharing, adaptation, distribution and reproduction in any medium or format, as long as you give appropriate credit to the original author(s) and the source, provide a link to the Creative Commons licence, and indicate if changes were made. The images or other third party material in this article are included in the article's Creative Commons licence, unless indicated otherwise in a credit line to the material. If material is not included in the article's Creative Commons licence and your intended use is not permitted by statutory regulation or exceeds the permitted use, you will need to obtain permission directly from the copyright holder. To view a copy of this licence, visit http://creativecommons.org/licenses/by/4.0/. 


\section{Introduction}

Infertility, a global health burden, is the failure of a sexually active, non-contracepting couple to conceived after 12 months of regular unprotected intercourse [1]. Infertility has become major public health challenge affecting more than $15 \%$ of all couples [2]. A number of factors causing reduction in male fertility has been documented which include increased scrotal temperature (e.g. as a consequence of varicocele), endocrine disturbances, genetic abnormalities, congenital or acquired urogenital abnormalities, immunological factors, malignancies, poor semen quality (oligozoospermia, asthenozoospermia, or teratozoospermia), urogenital tract infections [1]. Connubial and psychosocial stress, high cost of treatment [3], reduced longevity and risk factor for certain malignancies [4] are some of the deleterious effects of male infertility.

Chemically induced endocrine disruption and testicular damage may occur after administration of toxicants or potentially toxic drugs. The clinical symptoms of chemicallyinduced testicular disorder includes abnormalities in the testicular structure and alteration in its physiological functions [5, 6]. A group of xenobiotics known as endocrine disruptors may alter the physiological activities of biological systems, mediate hormonal balance, and/or adversely influence biological functions and activities of organs that hormones control or modulate, especially in reproductive systems [7].

Nitrobenzene is an industrial chemical predominantly used in aniline production, a raw material in dyestuffs and other products. Nitrobenzene is also employed in the manufacturing of compounds such as benzidine, quinoline, isocyanates, pesticides, and pharmaceutical products. Nitrobenzene has been found in air and as volatile compound in water and soil. Environmental exposure to nitrobenzene is expected to be primarily through inhalation of ambient air, ingestion of water, or dermal exposure to products and water containing nitrobenzene [8].

Phytochemicals are naturally occurring compounds regarded as one of the important origins of biologically active natural products [9-11]. The reported biological and pharmacological activities such as anticarcinogenic, anti-inflammatory, and antioxidant, and antimutagenic activities of these isolated active compounds from plants has awaken research interest towards development of more potent drugs to combat various diseases [12-14]. The bioactive compounds that has been recorded to be present in a number of plants may produce medicinal effects for in treatment of reproductive related disorders.

Vernonia amygdalina, commonly known as bitter life is a medicinal plant with several health benefits. The documented phytochemical constitutents of various fractions of Vernonia amygdalina includes epivernodalol, sesquiterpene lactones, elemanolide [15], edotides [16], terpenes, steroids, coumarins, flavonoids, phenolic acids, lignans, xanthones and anthraquinone [17], saponins and alkaloids [18]. These phytochemical constituents have been reported to be responsible for a number of medicinal valves of the plant such as antimicrobial activities [19], antioxidant properties [20, 21], anti-inflammatory [22] and antipyretic activity [23, 24]. The anti-malarial activity of Vernonia amygdalina essentially against $P$. falciparum was reported to be due to the presence sesquiterpenes lactones compounds which includes vernolide, vernodalin, hydroxy vernolides and the steroid related constituents, vernoniosid B1 and vernonoid B1 [25-27].

Based on the above mentioned, the objective of this study was to evaluate the endocrine-disrupting effects and male reproductive toxicity of nitrobenzene in wistar rats via assessment of sexual hormone levels, testicular functions and oxidative testicular damage markers. Moreover, to investigate the protective effect of methanolic leaf extract of Vernonia amygdalina against the nitrobenzeneinduced male reproductive toxicities.

\section{Materials and methods \\ Chemicals/ reagents}

High purity (> 99.7\%) Nitrobenzene was obtained from BDH chemical Poole England. Vitamin E (Alpha Tocopherol) is a product of Embassy pharmaceuticals. Thyroid stimulating hormone (TSH), luteinizing hormone $(\mathrm{LH})$, follicle stimulating hormone (FSH), prolactin, testosterone, triiodothyronine (T3), and tetraiodothyronine (T4). All other chemicals are of analytical grade and were obtained from Analar BDH Limited, Poole, England and Sigma-Aldrich Co. St Louis, Missouri, USA.

\section{Collection of plant material and preparation of extract}

Fresh leaves of Vernonia amygdalina were collected at the staff quarters in Kings University, Odeomu, Osun State. The leaf has been identified at IFE-Herbarium of Botany Department, Obafemi Awolowo University, Ile-Ife with Voucher number, IFE-16885. The Vernonia amygdalina leaves were washed and air-dried at room temperature in the Biochemistry laboratory, Kings University, Nigeria and pulverized using an electric blender. The powdered leaf was defatted in n-hexane using Soxhlet apparatus. Thereafter, methanolic extract was prepared by soaking the defatted leaf in $90 \%$ methanol for $72 \mathrm{~h}$. The resulting mixture was then filter and the filtrate was concentrated on water bath. The concentrated extract was lyophilized using Bosch freeze drying machine. The full chemical identification and bioactive compounds of Vernonia amygdalina has been earlier reported by Oladunmoye et al. [28] using gas chromatography-mass spectrometry (GC-MS). The technique reveals methyl-2-O-benzyl-darabinofuranoside, phytol, hexadecanoic acid, ethyl ester, squalene and 9, 12, 15, octadecatrienoic acid as the more abundant compounds (>85\% abundance) while N-[2- 
(dimethylamino)-5-pyrimidinyl] benzene sulfonamide, 9, 12, 15 and octadecatrien-1-ol, p-Menth-4(8)-en-9-ol has the less lesser abundance ( $<12 \%$ abundance) compounds Oladunmoye et al. [28].

\section{Experimental animals}

Thirty sexually matured 4-5 months old male albino rats were used in the study. The rats were procured from the Central Animal House, College of Medicine, University of Ibadan, Nigeria. The rats were acclimatized for a period of 2 weeks in the Animal House of Biochemistry unit, Department of Chemical Sciences, Kings University, Nigeria before treatment commenced. All animals were housed six rats per cage in plastic suspended cages under standard environmental conditions (12 h light/dark cycle) in a wellventilated rat house. The animals were fed with standard animal pellets and water ad libitum throughout the period of acclimatization and administration of the compounds. Administration of compounds to the rats were done orally for 14 consecutive days.

The experiment was carried out in accordance to the $\mathrm{NIH}$ guide for the use and care of laboratory animals and the study was approved by the Institution's Ethical Committee [29].

The rats were divided into five groups, six rats per group:

Group A: received distilled water daily and serve as the Control.

Group B: received $100 \mathrm{mg} / \mathrm{kg}$ Nitrobenzene.

Group C: received $100 \mathrm{mg} / \mathrm{kg}$ Nitrobenzene and 200

$\mathrm{mg} / \mathrm{kg}$ Vernonia amygdalina.

Group D: received $100 \mathrm{mg} / \mathrm{kg}$ Nitrobenzene and 400

$\mathrm{mg} / \mathrm{kg}$ Vernonia amygdalina.

Group E: Received single dose of $100 \mathrm{mg} / \mathrm{kg}$

Nitrobenzene and $400 \mathrm{mg} / \mathrm{kg}$ Vitamin E.

\section{Preparation of serum}

The rats were sacrificed $24 \mathrm{~h}$ after the last treatment by cervical dislocation and blood sample collected into clean, dry centrifuge tube. The blood was left for $10 \mathrm{~min}$ at room temperature to clot after which it was centrifuged at 4000 rpm for $20 \mathrm{~min}$ in an MSC (Essex, UK) bench centrifuge. The clear supernatant (serum) was aspirated using a Pasteur pipette into clean, dry sample bottles and then stored at $4{ }^{\circ} \mathrm{C}$ for biochemical analyses.

\section{Preparation of testes homogenate}

The testes were rinsed with $\mathrm{KCl}$, blotted and weighed. They were then chopped into bits and homogenized in four volumes of the homogenizing buffer $(0.1 \mathrm{M}$ Tris- $\mathrm{KCl}$, pH 7.4) using a Teflon homogenizer. The resulting homogenate was centrifuged at $12,500 \mathrm{~g}$ for $15 \mathrm{~min}$ in a cold centrifuge $\left(4^{\circ} \mathrm{C}\right)$, to obtain the post mitochondrial fraction.
The supernatant was collected and used for biochemical analyses.

\section{Biochemical analysis}

Protein content was measured using protocol described by Lowry et al. [30] using BSA as a standard. Lipid peroxidation was determined by method of Varshney and Kale [31]. The reduced GSH content in the testes were assessed according to the method documented by Buetler et al. [32].

\section{Gonadosomatic index}

Gonadosomatic index for each rat in all experimental groups were calculated by expressing the weight of the right testis over the pre-sacrifice body weight as a percentage as described by Parandin and Rohani [33].

$$
\begin{aligned}
& \text { Gonadosomatic index }(\mathrm{GSI}) \\
& \quad=[\text { gonad weight } / \text { total tissue weight }] \times 100 \% \text {. }
\end{aligned}
$$

\section{Sex hormonal assay}

Quantitative measurement of Total testosterone Hormone Concentration in rat serum was by a Microplate Enzyme Immunoassay as described by the kit's manufacturer (Monobind Inc. USA).

\section{Reproductive hormonal assay}

Luteinizing Hormone (LH) concentration in rat serum was determined by a Microplate Enzyme Immunoassay using protocol designed by the kit's manufacturer (Monobind Inc. USA). Follicle Stimulating (FSH) Hormone Concentration was analysed in rat serum by a $\mathrm{Mi}$ croplate Immunoenzymometric assay following the kit's manufacturer procedure (Monobind Inc. USA).

\section{Thyroid hormonal assay}

Total Triiodothyronine (T3) and Total thyroxine (T4) hormones concentration were measured in serum of the rats using Microplate Enzyme Immunoassay while Thyrotropin (TSH) Hormone Concentration was determined using

Table 1 Influence of MLVA on body weight gain, testicular and epididymal weight of rats treated with nitrobenzene

\begin{tabular}{llll}
\hline Groups & $\begin{array}{l}\text { Body weight } \\
\text { gain (g) }\end{array}$ & $\begin{array}{l}\text { Testicular } \\
\text { weight (g) }\end{array}$ & $\begin{array}{l}\text { Epididymis } \\
\text { weight (g) }\end{array}$ \\
\hline Group I & $11.96 \pm 2.38$ & $2.74 \pm 0.15$ & $0.15 \pm 0.05$ \\
Group II & $6.36 \pm 1.03^{*}$ & $2.05 \pm 0.09^{*}$ & $0.10 \pm 0.03^{*}$ \\
Group III & $15.85 \pm 1.39^{* \#}$ & $2.25 \pm 0.21^{* \#}$ & $0.14 \pm 0.04^{\text {\# }}$ \\
Group IV & $18.66 \pm 1.92^{* \#}$ & $2.46 \pm 0.14^{\#}$ & $0.17 \pm 0.05^{* \#}$ \\
Group V & $20.77 \pm 2.23^{* \#}$ & $3.01 \pm 0.11^{\#}$ & $0.15 \pm 0.03^{\text {\# }}$ \\
\hline
\end{tabular}

Data are given as mean \pm SD of rats per group. $n=6$. MLVA: methanolic leaf extract of Vernonia amygdalina, *: Values differ significantly from group I (control) $(P<0.05)$. \#: Values differ significantly from group II 


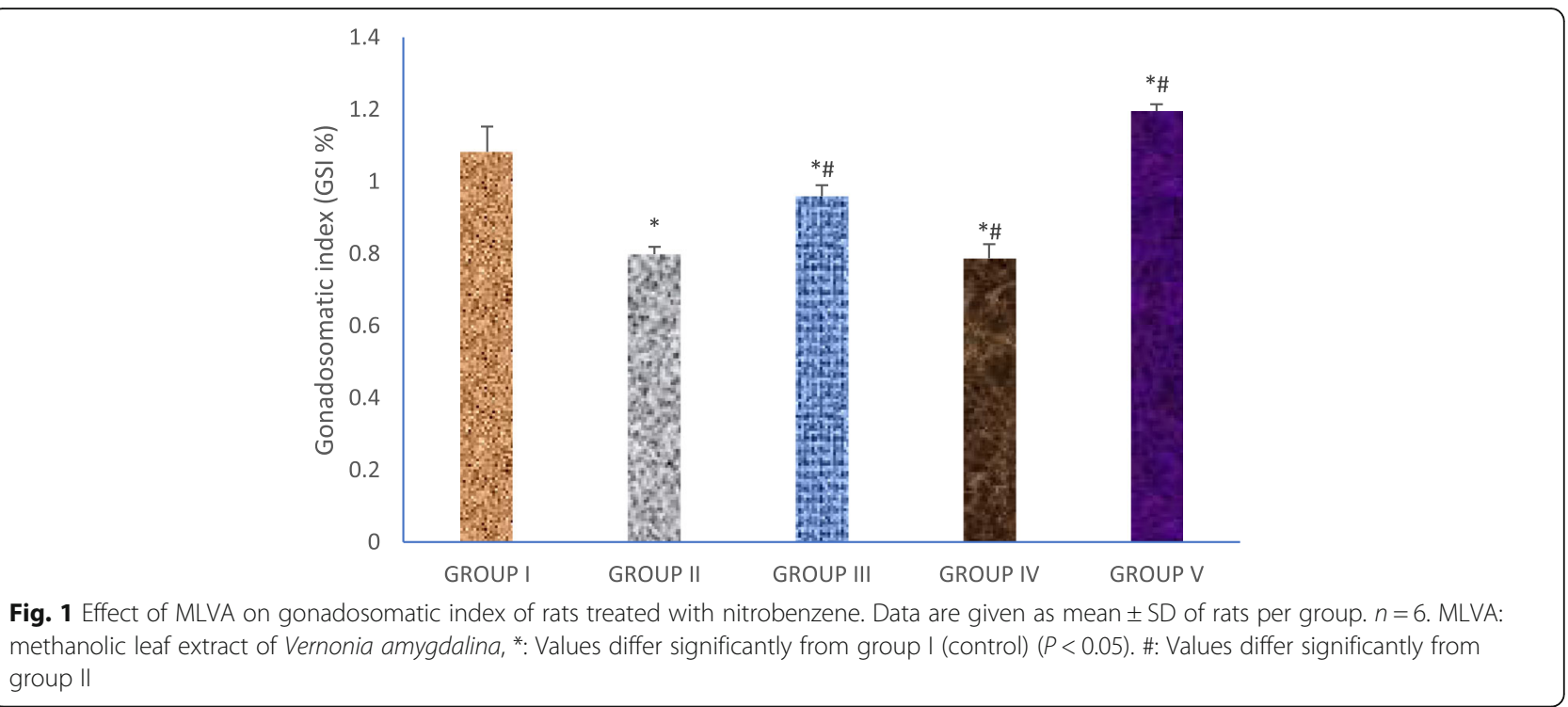

Microplate Immunoenzymometric assay as described by the kit's manufacturer (Monobind Inc. USA).

\section{Prolactin hormonal assay}

Quantitative analysis of Hormone Concentration in rat serum by a Microplate Sequential Immunoenzymometric assay as described by the kit's manufacturer (Monobind Inc. USA).

\section{Histological examination}

The testes were immediately fixed in $10 \%$ formalin and embedded in paraffin wax. Fine sections $(7-9 \mathrm{~mm}$ thickness) of the testes were then dewaxed in xylene, hydrated in decreasing percentage of alcohol and stained with hematoxylin and eosin. The stained sections were observed under a Leitz microscope and their photomicrograph taken at X 100 with a Canon (Meville, NY) Power Shot G2 Digital Camera.

\section{Statistical analysis}

Data were expressed as mean \pm standard deviation (mean \pm $\mathrm{SD})$ and analyzed using one-way analysis of variance (ANOVA) with the aid of SPSS 12.0 computer software package (SPSS Inc.; Chicago, U.S.A). Student's t-test was employed for comparison between two sets of data and differences at $P<0.05$ were considered significant.

\section{Results and discussion}

A large number of chemicals present in our environment may have the ability of disrupting the endocrine system [34]. Many of these chemicals can interfere with the development of the endocrine system and of the
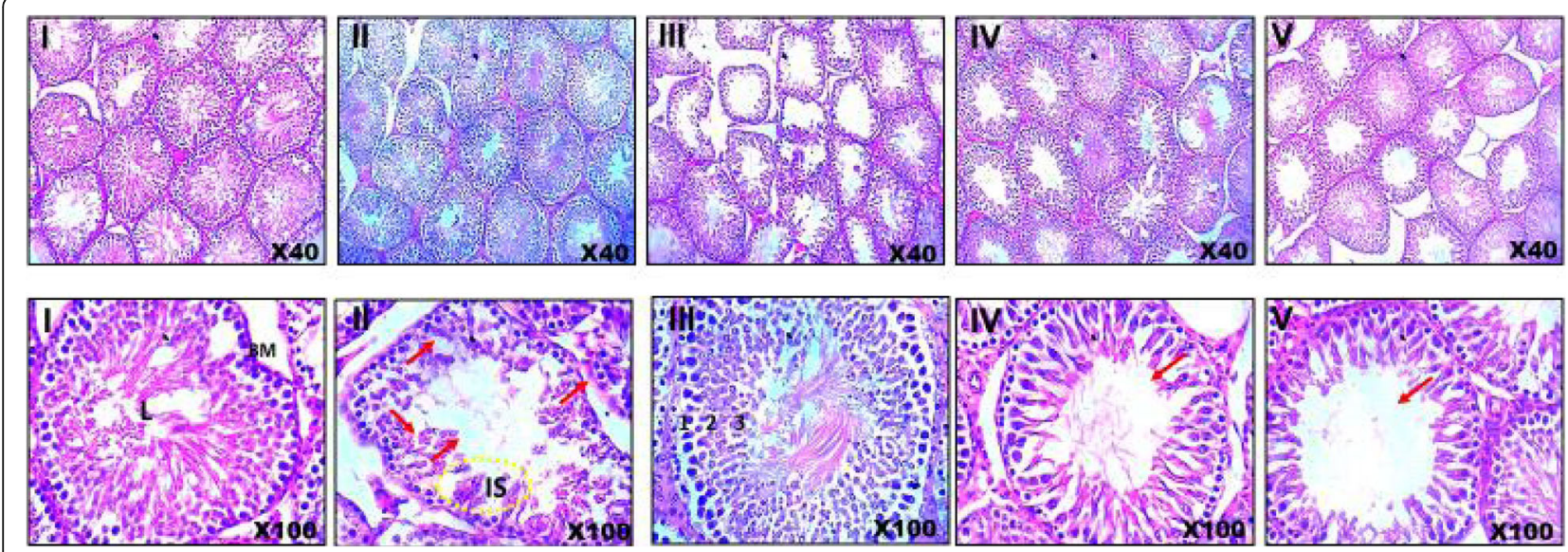

Fig. 2 Photomicrographs of the testicular Histomorphology of adult male Wistar rats across treated groups. H\&E stain $\times 40$ and $\times 100$. The seminiferous epithelium and basement membrane (BM), The lumen (L) and interstitial space (IS) containing interstitial cells, spermatogonium (SG) $\left(1^{0}, 2^{0}, 3^{0}\right)$ are well demonstrated across the testicular sections but not conspicuous at $\times 40$ magnification 


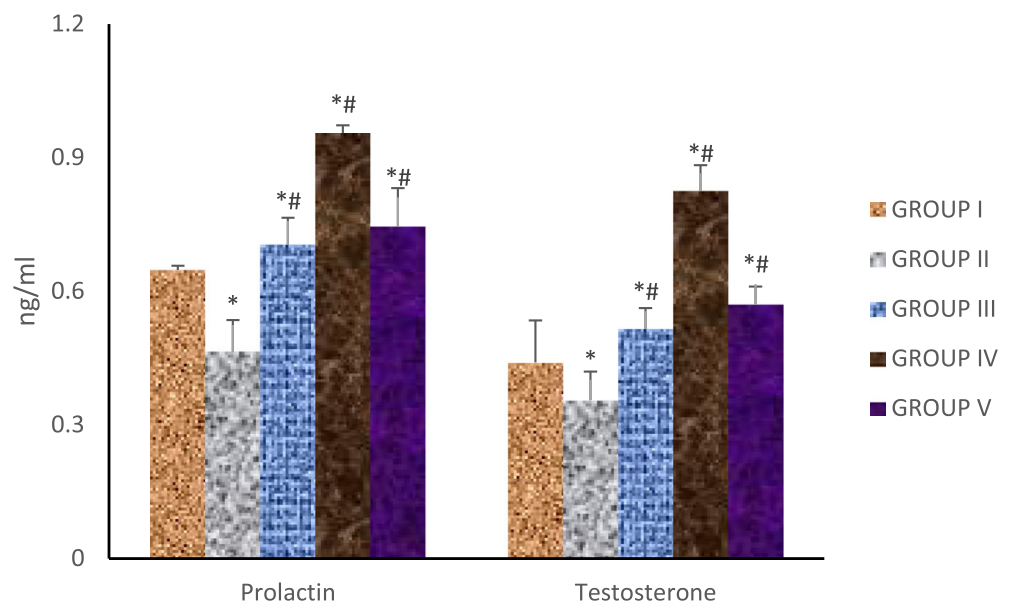

Fig. 3 Effect of MLVA on testosterone and prolactin of rats treated with nitrobenzene. Data are given as mean \pm SD of rats per group. $n=6$. MLVA: methanolic leaf extract of Vernonia amygdalina, ${ }^{*}$ : Values differ significantly from group I (control) $(P<0.05)$. \#: Values differ significantly from group II

organs that respond to endocrine signals in organisms indirectly exposed during prenatal and/or early postnatal life; effects of exposure during development are permanent and irreversible [35]. Mammalian testicular and epididymal cells are highly prone to oxidative damage as a result of exposure to environmental or toxic chemicals [36]. Results in this study demonstrated that exposure of Nitrobenzene caused significant decrease in testicular and epididymal weights in rats treated with nitrobenzene alone (Table 1 and Fig. 1). Decline in testes weights in this study was confirmed by the histopathological assessments. Most of the somniferous tubules were degenerated and atrophied as shown in Fig. 2.

Previous experimental findings have revealed that long-term exposure of rats to high dose of xenobiotics (dicofol) caused reduction in testes and epididymis weights in rats with concomitant decrease in diameter of somniferous tubules, spermatogenic, Leydig and Sertoli cells $[37,38]$. Furthermore, studies have shown that the epididymis and accessory sex organs require constant androgenic stimulation to preserve their normal structural and functional integrity [39]. Thus, the decrease in the epididymal and other related sex organs weights in the treated rats may be due to intermittent supply of androgens [40]. It may be concluded that nitrobenzene influence testes and accessory reproductive organs by inhibiting androgen biosynthesis and/or antagonizing the action of androgens [41]. Also, nitrobenzene may also be having direct effects on the normal function of the hypothalamo-pituitary-gonadal axis. However,

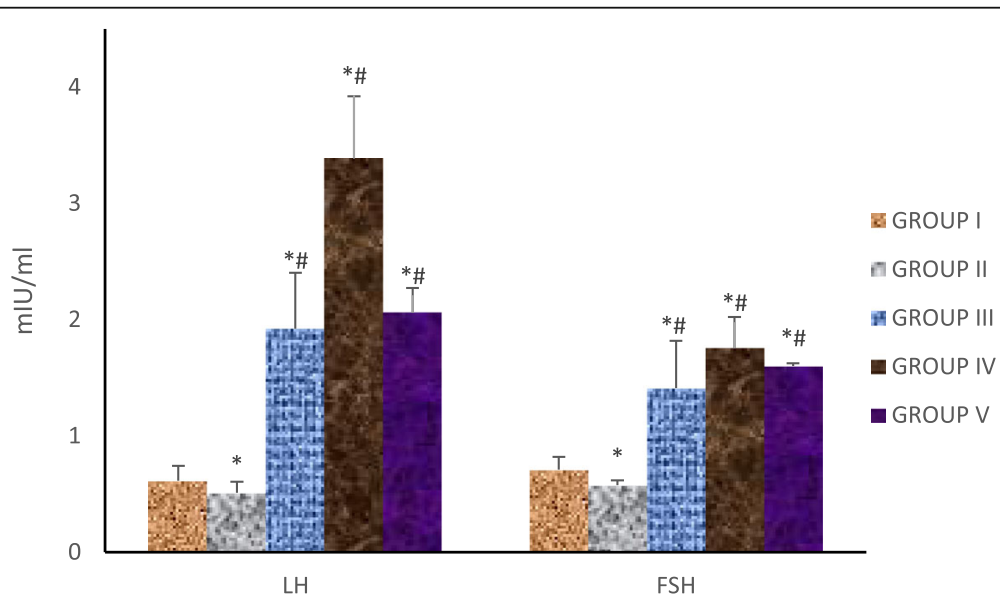

Fig. 4 Influence of MLVA on luteinizing hormone $(\mathrm{LH})$ and follicle stimulating hormone (FSH) of rats treated with nitrobenzene. Data are given as mean \pm SD of rats per group. $n=6$. MLVA: methanolic leaf extract of Vernonia amygdalina, ${ }^{*}$ : Values differ significantly from group I (control) $(P<$ 0.05). \#: Values differ significantly from group II 


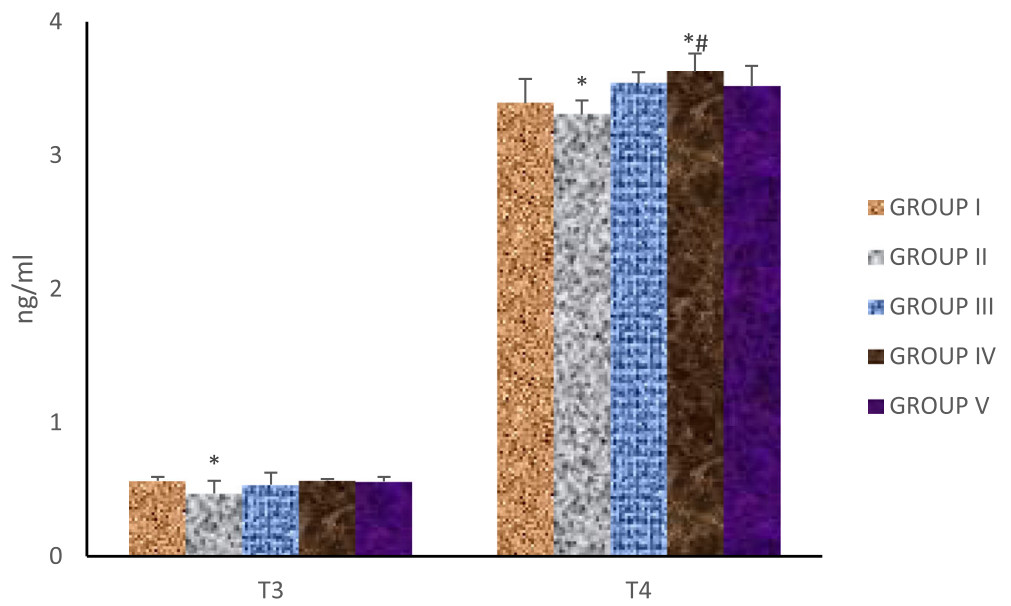

Fig. 5 Effect of MLVA on tri-iodothyronine $\left(T_{3}\right)$ and thyroxine $\left(T_{4}\right)$ of rats treated with nitrobenzene. Data are given as mean $\pm S D$ of rats per group. $n=6$. MLVA: methanolic leaf extract of Vernonia amygdalina, ${ }^{*}$ : Values differ significantly from group I (control) $(P<0.05)$. \#: Values differ significantly from group II

treatment with methanolic leaf extract of Vernonia amygdalina significantly reverse the weights of the organs close to the control group.

One of the most important steroid sex-hormone in male mammal (e.g. rats) is testosterone, and it is secreted under the regulation of complex neuroendocrine processes in the leydig cells of the testes [42, 43]. In this study, testosterone level was significantly decreased in nitrobenzenetreated groups (Fig. 3). This significant decrease in testosterone level may be as a result of direct damage of nitrobenzene on leydig cells, which are the main site of testicular androgen biosynthesis. Notably, there was dosedependent increase in the level of testosterone following the administration of methanolic leaf extract of Vernonia amygdalina close to the those in the control group. This suggest that the extract may have protective effect on the Leydig cells thus enhance androgen biosynthesis.

Luteinizing hormone (LH), a glycoprotein released from the anterior pituitary has its main biological role in stimulating the production of testosterone by leydig cells of the testes in male mammals. LH activities is monitored through the negative feedback control of gonadoliberin $(\mathrm{GnRH}$, LHRH) secretion at the hypothalamic level by testosterone in the male [42]. The result of this study revealed that there is a marked decline in $\mathrm{LH}$ level in rats administered with nitrobenzene alone (Fig. 4). Previous findings demonstrated that the alteration in LH level led to degeneration of seminiferous epithelium and damage of germinal elements with concomitant decrease in the number of spermatids, sperm production in the testes as well as increase abnormality of

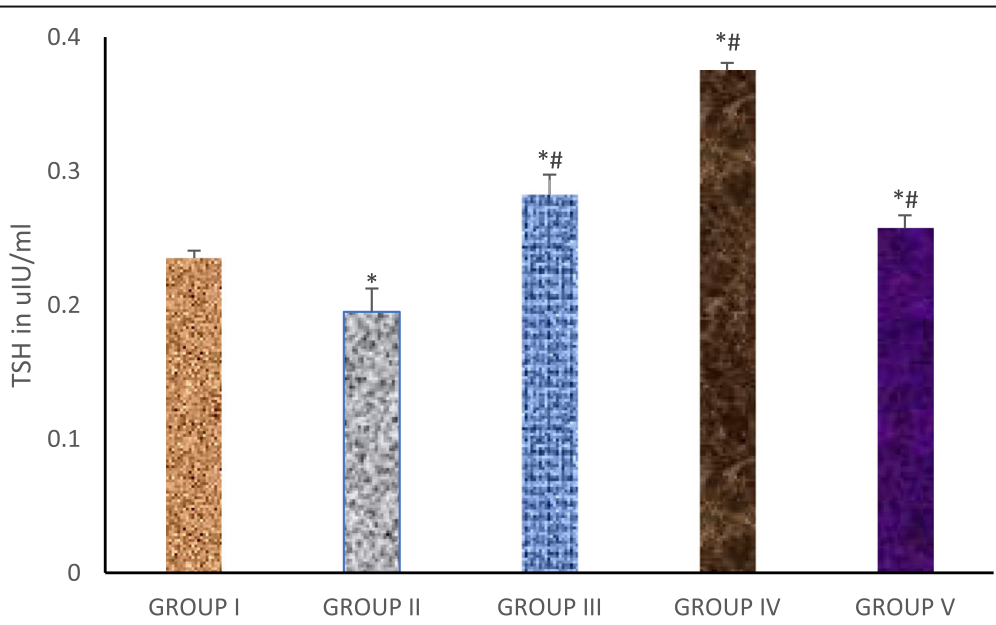

Fig. 6 Effect of MLVA on Thyrotropin (TSH) Hormone of rats treated with nitrobenzene. Data are given as mean \pm SD of rats per group. $n=6$. MLVA: methanolic leaf extract of Vernonia amygdalina, *: Values differ significantly from group I (control) $(P<0.05)$. \#: Values differ significantly from group II 


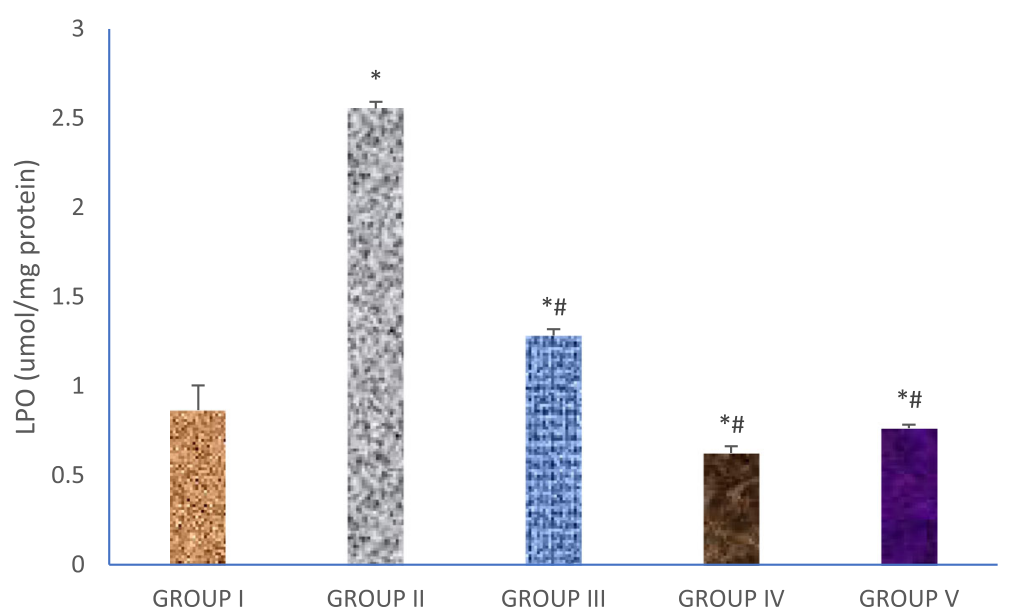

Fig. 7 Effect of MLVA on testicular lipid peroxidation (LPO) of rats treated with nitrobenzene. Data are given as mean $\pm S D$ of rats per group. $n=$ 6. MLVA: methanolic leaf extract of Vernonia amygdalina, *: Values differ significantly from group I (control) $(P<0.05)$. \#: Values differ significantly from group II

sperms [44]. However, treatment with chosen concentrations of methanolic leaf extract of Vernonia amygdalina attenuated the toxic effects of nitrobenzene.

Similarly, there is a marked decline in FSH level in rats administered with nitrobenzene alone (Fig. 4). FSH have been documented to have influence on the sertoli cells of the seminiferous tubules leading to secretion of androgen binding protein which are transported to other germ cells and the epididymis where sperm maturation take place through the enhancement of testosterone [44]. Atrophy and degeneration of seminiferous together with the Sertoli and leydig cells as revealed in the histological findings could also account for the decrease level of FSH. Treatment with various concentrations of methanolic leaf extract of Vernonia amygdalina offers protective effects against nitrobenzene induced FSH damage. This shows that the extract contains bioactive compounds and phytochemicals which are capable of enhancing sperm maturation and enhance FSH activities.

Hyperplasia, thyroid follicular cell hypertrophy, and the development of thyroid tumors in rats are linked with alteration of thyroid hormones homeostasis by a number of toxicants [45, 46]. Capen [46] documented that xenobiotics elicit their deleterious effects on thyroid hormones by either accelerating peripheral elimination of the thyroid hormones or directly acting on the thyroid gland. There is a decrease in thyroxine $\left(\mathrm{T}_{4}\right)$ and triiodothyronine $\left(\mathrm{T}_{3}\right)$ levels in rats treated with nitrobenzene only (Fig. 5) which indicates hypothyroidism. Maran and Aruldhas [47] reported that hypothyroidism mediated arrest of proliferation and differentiation of germ cells and also significantly decreased seminiferous

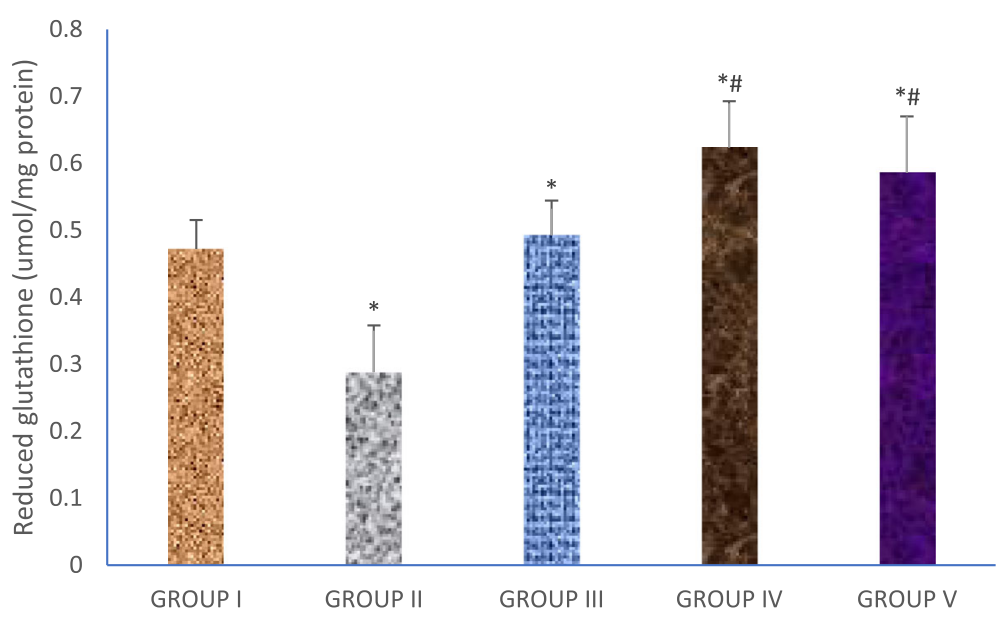

Fig. 8 Influence of MLVA on testicular glutathione (GSH) content of rats treated with nitrobenzene. Data are given as mean $\pm S D$ of rats per group. $n=6$. MLVA: methanolic leaf extract of Vernonia amygdalina, * Values differ significantly from group I (control) $(P<0.05)$. \#: Values differ significantly from group II 
tubule and lumen diameter. However, methanolic leaf extract of Vernonia amygdalina ameliorated all these adverse effects of nitrobenzene in a dose-related manner.

Furthermore, TSH level was significantly declined following the exposure of nitrobenzene to the experiment rats (Fig. 6). The anterior lobe of the pituitary gland regulates thyroid hormones through secretion of TSH. This decline indicated adverse effects of nitrobenzene on the hypothalamic-pituitary-thyroid axis. Several studies have documented the influence of thyroid hormones on the testicular functions in sperm production (spermatogenesis) and steroidogenesis [48, 49]. However, oral administration of methanolic leaf extract of Vernonia amygdalina attenuated the decrease in TSH mediated by nitrobenzene in a dose-related manner.

As shown in Fig. 3, exposure of rat to nitrobenzene caused decrease in prolactin level in rats treated with nitrobenzene alone. Prolactin hormone, produced from the lactotrophs of the anterior pituitary, consist a single polypeptide chain containing approximately 200 amino acids. Its primary biological function is to stimulate mammary gland growth, induction and maintenance of milk production. Prolactin involvement in steroidogenesis has been suggested, acting synergistically with luteinizing hormone (LH). However, at high concentrations, prolactin tends to halt steroidogenesis as well as inhibiting $\mathrm{LH}$ and FSH synthesis at the pituitary gland [50, 51]. Clinically, prolactin hormone is routinely measured to determine and diagnosis hyperprolactinemia $[52,53]$. Treatment with Vernonia amygdalina reversed level of prolactin to a moderate level suggesting its role in steroidogenesis.

\section{Conclusion}

This present study establishes that Nitrobenzene-induced reproductive toxicity by interfering with testicular steroidogenesis. Nitrobenzene adversely affects testicular steroidogenic vitality by down-regulating hormonals activities. Also, Nitrobenzene disrupted regulatory pathway in the hypothalamo-pituitary-gonadal axis by inhibiting testosterone release from gonads and; LH and FSH produce from the anterior portion of pituitary gland. The protection of Nitrobenzene-induced hypothyroidism, alternation of steroidogenic pathways and hormonal disruption in rat by methanolic leaf extract of Vernonia amygdalina in this present study is attributed to its enhancement of androgen biosynthesis, promoting hormonals activities, downregulating testicular lipid peroxidation (Fig. 7) and ensuring endogenous antioxidant status (Fig. 8).

\section{Abbreviations}

FSH: Follicle stimulating hormone; GSH: Reduced glutathione; LH: Luteinizing hormone; MDA: Lipid peroxidation; MLVA: Methanolic leaf extract of Vernonia amygdalina; PRL: Prolactin; T3: Triiodothyronine; T4: Tetraiodothyronine;

TSH: Thyroid stimulating hormone

\section{Acknowledgments}

The authors wish to appreciate the technical supports of Mr. Adeleke Opeyemi Samson of the Department of Anatomy, College of Health Sciences, Osun State University, Osogbo, Nigeria and Mr. Ogunleke Olumide Ayobami of the Department of Chemical Pathology, Ladoke Akintola University Teaching Hospital, Osogbo, Nigeria.

\section{Authors' contributions}

OJO conceived the study, and participated in its design and execution and helped to draft the manuscript; OMO participated in the design,

coordination and helped to draft the manuscript; OTO participated in the execution of the study; ODB participated in the execution of the study; OOA participated in the execution of the study. All authors read and approved the final manuscript

\section{Funding}

This research was done using authors personal funds without specific grant from any funding agency in the public, commercial, or not-for-profit sectors.

Availability of data and materials

Please contact corresponding author for data requests.

Ethics approval and consent to participate

All experimental procedures were approved by the Institutional Animal Ethics Committee.

Consent for publication

All the authors contributed, agreed, submitted, and revised this manuscript.

\section{Competing interests}

The authors declare that they have no competing interests.

\section{Author details}

${ }^{1}$ Department of Chemical Sciences, Faculty of Science, Kings University, Ode-Omu, Osun State, Nigeria. ${ }^{2}$ Phytomedicine and Toxicology Laboratories, Department of Biochemistry, Faculty of Basic and Applied Sciences, Osun State University, Osogbo, Nigeria.

Received: 5 November 2019 Accepted: 26 February 2020

Published online: 07 March 2020

\section{References}

1. World Health Organization. WHO manual for the standardized investigation and diagnosis of the infertile couple. Cambridge: Cambridge University Press; 2000. https://doi.org/10.1016/0968-8080(94)90122-8.

2. Sabanegh E, Agarwa A. Male infertility. In: Wein a, editor. Campbell-walsh urology. 10th ed. Philadelphia: Elsevier Saunders; 2011. p. 616-47. https:// doi.org/10.1016/b978-1-4160-6911-9.00021-9.

3. Smith JF, Walsh TJ, Shindel AW, Turek PJ, Lauri HW, Patricia P, Katz P. Sexual, marital, and social impact of a man's perceived infertility diagnosis. J Sex Med. 2009;6(9):2505-15. https://doi.org/10.1111/j.1743-6109.2009.01383.x.

4. Walsh TJ, Croughan MS, Schembri M, Chan JM, Turek PJ. Increased risk of testicular germ cell cancer among infertile men. Arch Intern Med. 2009; 169(4):351-6. https://doi.org/10.1001/archinternmed.2008.562.

5. Wang YJ, Yan J, Yin F, Li L, Qin YG, Meng CY, Lu RF, Guo L. Role of autophagy in cadmium-induced testicular injury. Hum Exp Toxicol. 2017;36: 1039-48. https://doi.org/10.1177/0960327116678300.

6. Abd EA, Fahim AT, Sadik N, Ali BM. Resveratrol and curcumin ameliorate di(2-ethylhexyl) phthalate induced testicular injury in rats. Gen Comp Endocrinol. 2016;225:45-54. https://doi.org/10.1016/j.ygcen.2015.09.006.

7. Daston GP, Cook JC, Kavlock RJ. Uncertainties for endocrine disrupters: our view on progress. Toxicol Sci. 2003;74:245-52. https://doi.org/10.1093/toxsci/kfg105.

8. International Programme on Chemical Safety (IPCS), Nitrobenzene. Environmental Health Criteria 230. Geneva: WHO; 2003.

9. Gulcin I, Mshvildadze V, Gepdiremen A, Elias R. Antioxidant activity of a triterpenoid glycoside isolated from the berries of Hedera calchica: 3-O-(bD-glucopyranosyl)-hederagenin. Phytother Res. 2006;20:130-4. https://doi. org/10.1002/ptr.1821.

10. Koksal E, Gulcin I, Beyza S, Sarikaya O, Bursal E. In vitro antioxidant activity of silymarin. J Enzyme Inhib Med Chem. 2009:24(2):395-404. https://doi.org/10. 1080/14756360802188081. 
11. Liu S, Manson JF, Lee IM, Cole SR, Hennekens CH, Willett WC, Buring JE, et al. Fruit and vegetable intake and risk of cardiovascular disease: the women's health study. Am J Clin Nutr. 2000;72:922-8. https://doi.org/10. 1093/ajcn/72.4.922.

12. Rao AV, Gurfinkel DM. The bioactivity of saponins, triterpenoid and steroidal glycosides. Drug Metabol Drug Interact. 2000;17(1-4):211-35. https://doi. org/10.1515/dmdi.2000.17.1-4.211.

13. Wu SJ, Lin YH, Chu CC, Tsai YH, Jane CJ. Curcumin or saikosaponin a improves hepatic antioxidant capacity and protects against CCl4-induced liver injury. J Med Food. 2008;11(2):224-9. https://doi.org/10.1089/jmf.2007.555.

14. Yang H-L, Chen S-C, Chang N-W, Chang J-M, Lee M-L, Tsai P-C, et al. Protection from oxidative damage using Bidens pilosa extracts in normal human erythrocytes. Food Chem Toxicol. 2006;44:1513-21. https://doi.org/ 10.1016/j.fct.2006.04.006.

15. Erasto P, Grierson DS, Afolayan AJ. Bioactive sesquiterpenes lactones from the leaves of $V$. amygdalina. J Ethnopharmacol. 2006;106:117-20. https://doi. org/10.1016/j.jep.2005.12.016.

16. Izeybigie EB. Discovery of water solubleanticancer agents (Edotides) from a vegetable found in Benin City. Nigeria Exper Bio Med. 2003;228:293-9. https://doi.org/10.1177/153537020322800308.

17. Cimanga RK, Tona L, Mesia K, Musuamba CT, De Bruyne T, Apers S, Hernan N, Miert VS, Pieters L, Totte J, Vlietink AJ. In vitro antiplasmodia acivity of extravts and fractions of seven medicinal plants used in the democratic republic of Congo. J Ethnopharmacol. 2004;93:27-32. https://doi.org/10. 1016/j.jep.2004.02.022.

18. Muraina IA, Adaudi AO, Mamman M, Kazeem HM, Picard J, McGaw LJ, Eloff JN. Antimycoplasmal activity of some plant species from northern Nigeria compared to the currently used therapeutic agent. Pharm Biol. 2010;48: 1103-7. https://doi.org/10.3109/13880200903505633.

19. Iwu MW, Duncan AR, Okunji CO. New antimicrobials of plant origin. In: Janick J, editor. Perspectives on new crops and new uses. Alexandria: ASHS Press; 1999.

20. Igile GO, Oleszek W, Jurzysta M, Burda S, Fafunso M, Fasanmade AA. Flavonoids from $V$. amygdalina and their antioxidant activities. J Agric Food Chem. 1994;42:2445-8. https://doi.org/10.1021/jf00047a015.

21. Adesanoye OA, Farombi EO. Hepatoprotective effects of $V$. amygdalina (Astereaceae) in rats treated with carbon tetrachloride. Exp Toxicol Pathol. 2010;62:197-206. https://doi.org/10.1016/j.etp.2009.05.008.

22. Ibrahim G, Abdurahman EM, Ibrahim H, Ibrahim NO. Comparative cytomormological studies on the studies of $\mathrm{V}$. amygdalina Del. and $\mathrm{V}$. Kotschyama. Nig J Botany. 2010;23(1):133-42.

23. Adiukwu CP, Agaba A, Nambatya G. Pharmacognostic, antiplasmodial and antipyretic evaluation of the aqueous extract of $\mathrm{V}$. amygdalina leaf. Int J Biol Chem Sci. 2011;5(2):709-16. https://doi.org/10.4314/ijbcs.v5i2.72134.

24. Okokon JE, Onah MI. Pharmacological studies on root extract of $V$. amygdalina. Nig J Prod Med. 2004:8:59-61. https://doi.org/10.4314/njnpm.v8i1.11818.

25. Kaoul AM, Mahiou-Leddet V, Hutter S, Ainouddine S, Hassani S, Yahaya I, Azas N, Olliver E. Antimalarial activity of crude extracts from nine African medicinal plants. J Ethnopharmacol. 2008;116:74-83. https://doi.org/10. 1016/j.jep.2007.11.001.

26. Magboul AZI, Bashir AK, Khalid SA, Farouk A. Anti-microbial activity of vernolein and vernodalin. Fitoterapia. 1997;68:83-4.

27. Tona L, Cimanga RK, Mesia K, Apers S. In vitro anti-plasmodial activity of extracts and fractions from seven medicinal plants used in the Democratic Republic of Congo. J Ethnopharmaco. 2004;193:27-32. https://doi.org/10. 1016/j.jep.2004.02.022.

28. Oladunmoye MK, Afolami OI, Oladejo BO, Amoo IA, Osho BI. Identification and quantification of bioactive compounds present in the plant Vernonia amygdalina Delile using GC-MS technique. Nat Prod Chem Res. 2019;7:356 https://doi.org/10.4172/2329-6836.1000356.

29. National Research Council (NRC). Guide for the care and use of laboratory animals. 8th ed: The National Academies Press; 2011. https://doi.org/10. $17226 / 12910$.

30. Lowry OH, Rosenbrough NJ, Farr AL, Randall RJ. Protein measurement with the Folin phenol reagent. J Biol Chem. 1951;193:265-75.

31. Varshney R, Kale RK. Effect of calmodulin antagonist on radiation induced lipid peroxidation in microsomes. Int J Radiat Biol. 1990;58:733-43. https:// doi.org/10.1080/09553009014552121.

32. Buetler E, Duron O, Kelly BM. Improved method for the determination of blood glutathione. J Lab Clin Med. 1963:61:882-8. https://doi.org/10.1097/ 00003072-199111000-00028.
33. Parandin R, Rohani SA. Effects of oil extract of Ocimum gratissimum leaves on the reproductive function and fertility of adult male rats. J Appl Biol Sci. 2010;4(2):1-4.

34. Dalsenter PR, Faqi AS, Chahoud I. Serum testosterone and sexual behavior in rats after prenatal exposure to lindane. Bull Environ Contam Toxicol. 1997:59:360-6. https://doi.org/10.1007/s001289900486.

35. Colborn T, Vom Saal FS, Soto AM. Developmental effects of endocrinedisrupting chemicals in wildlife and humans. Environ Health Perspect. 1993; 101:378-84. https://doi.org/10.1289/ehp.93101378.

36. El-Kashoury AA, Afrah F, Salama AF, Adel I, Selim Al, Mohamed RA. 2010. Chronic exposure of Dicofol promotes reproductive toxicity in male rats. Life Sci J. 2010;7(3):5-19. https://doi.org/10.1016/j.reprotox.2009.10.003.

37. Brown MA, Casida JE. Metabolism of a dicofol impurity alpha-chloro-DDT, but not dicofol or dechlorodicofol, to DDE in mice and a liver microsomal sytem. Xenobiotica. 1987:17:1169-74. https://doi.org/10.3109/ 00498258709167409

38. Jadaramkunti UC, Kaliwal BB. Dicofol formulation induced toxicity on tests and accessory reproductive organs in albino rats. Bull Environ Contam Toxicol. 2002;69:741-8. https://doi.org/10.1007/s00128-002-0123-5.

39. Mann T. Secretory function of the prostate, seminal vesicle and other male accessory organs of reproduction. J Reprod Fertil. 1974;37:179-88. https:// doi.org/10.1530/jff.0.0370179.

40. Mathur PP, Chattopadhyay S. Involvement of lysosomal enzymes in flutamide-induced stimulation of rat testis. Andrologia. 1982;14:171-6. https://doi.org/10.1111/j.1439-0272.1982.tb03120.x.

41. Prasad RS, Vijayan E. A new non-hormonal antifertility drug DL-204. I- effects on testes and accessory glands of reproduction in male rats. Contraception. 1987;36(5):557-66. https://doi.org/10.1016/0010-7824(87)90008-4.

42. Gornall AG, Goldbery DM. Hepatobiliary disorders. In: Allan G, editor Applied Biochemistry of Clinical Disorders. Hagerstown: Gornall, Inc. Virginia Venue; 1980. p. 164-92.

43. Robinson WF, Huntable CR. Clinicopathological principles for veterinary medicine. New York: Cambridge Univ. Press; 1988.

44. Mably TA, Bjerke DL, Moore RW, Gerndron FA, Peterson RW. In utero and lactation exposure of male rats to 2, 3, 7, 8 tetrachloro dibenzo-p-dioxin. Toxicol Appl Pharmacol. 1992;114:118-26. https://doi.org/10.1016/0041008x(92)90103-y.

45. Hill RN, Erdreich LS, Paynter OE, Roberts PA, Rosenthal SL, Wilkinson CF. Thyroid follicular cell carcinogenesis. Fundam Appl Toxicol. 1989;12:629-97. https://doi.org/10.1093/toxsci/12.4.629.

46. Capen CC. Toxic responses of the endocrine system. In: Klaassen CD, editor. Casarett and Doull's toxicology : the basic science of poisons. New York: McGraw-Hill; 1996. p. 617-40. https://doi.org/10.1016/s0378-4274(96)90054-5.

47. Maran RR, Aruldhas MM. Adverse effects of neonatal hypothyroidism on Wistar rat spermatogenesis. Endocr Res. 2002;28(3):141-54. https://doi.org/ 10.1081/erc-120015051.

48. Mendis-Handagama SM, Siril-Ariyaratne HB. Leydig cells, thyroid hormones and steroidogenesis. Indian J Exp Biol. 2005;43:939-62.

49. Wagner MS, Wajner SM, Maia AL. The role of thyroid hormone in testicular development and function. J Endocrinol. 2008;199:351-65. https://doi.org/ 10.1677/joe-08-0218

50. Maddox PR, Jones DL, Mansel RE. Basal prolactin and total lactogenic hormone levels by microbioassay and immunoassay in normal human sera. Acta Endocrinol. 1991;125(6):621-7. https://doi.org/10.1530/acta.0.1250621.

51. Gonzalez ER. Hyperprolactinemia: still perplexing but eminently treatable. JAMA. 1979;242(5):401-2. https://doi.org/10.1001/jama.1979. 03300050003001.

52. Tolis G. Prolactin: physiology and pathology. Hospital Practice. 1980;15(2): 85-95. https://doi.org/10.1080/21548331.1980.11946556.

53. Balagura S, Frantz AG, Housepian EM, Carmel PW. The specificity of serum prolactin as a diagnostic indicator of pituitary adenoma. J Neurosurg. 1979; 51(1):42-6. https://doi.org/10.3171/jns.1979.51.1.0042.

\section{Publisher's Note}

Springer Nature remains neutral with regard to jurisdictional claims in published maps and institutional affiliations. 